\section{Routine Testing of Folate Levels in Geriatric Assessment for Dementia}

To the Editor:-Folate deficiency is well established as a cause of megaloblastic anemia, but its relationship to dementia is less certain. In 1967, Strachan and Henderson ${ }^{1}$ reported on two patients with dementia who were found to have megaloblastic anemias due to folate deficiency. Treatment with folic acid cured both the anemia and the dementia in one patient and resulted in marked improvement of mental status in the other patient. Sneath et $\mathrm{al}^{2}$ found a significant correlation between low red-cell folate and severity of dementia on mental assessment scores. Since the dissemination of these reports and others, folic acid deficiency is usually included in the differential diagnosis of treatable dementias. Thus in many geriatric assessment/evaluation programs serum folate or red-blood-cell folate, or both, are measured as part of the routine testing.

Larson et $\mathrm{al}^{3}$ found the cost of screening blood tests per diagnosis of low folate level to be $\$ 1,001$, but, if determined only in those with abnormal CBCs, the cost was reduced somewhat to $\$ 842$. Thus they suggested folate testing be done on a selective basis. In 60 consecutive patients with progessive intellectual deterioration, Freemon ${ }^{4}$ found folate levels to be "unrewarding." Fox et al $^{5}$ evaluated 40 patients with "senile dementia" with laboratory tests including routine serum folate levels. Only two patients had low levels on initial testing, one of whom showed a normal level on retesting. The other was treated and showed no improvement in his dementia. Mulley, ${ }^{6}$ in reviewing the differential diagnosis of dementia, states "red-cell folate estimations should be limited to patients whose diet was grossly inadequate . . . and who have megaloblastic anemia." Despite the findings cited above, folate levels continue to be listed in the "standard dementia workup."7

In the Geriatric Assessment Service of the San Francisco Institute on Aging at Mount Zion Hospital and Medical Center, we reviewed the results of serum and red-blood-cell folate testing for all patients undergoing outpatient geriatric assessment from January 1985 to July 1987. One hundred seventy-two patients with a mean age of 77.5 years were surveyed during that time. Nine of the 172 were found to have an anemia, but none of the nine was clearly macrocytic, and none was folate-deficient.

One hundred two patients, or $59.3 \%$ of the total, had serum and red-cell folate levels obtained. Of the 102 patients tested, only one had a low serum folate, and one other had a low red-blood-cell folate. Neither of these patients was macrocytic or had an anemia, but both had cognitive deficits (as did $72 \%$ of the geriatric assessment patients) by the usual clinical and mental status testing criteria (Jacob Cognitive Capacity Screening and neuropsychological evaluation). The one patient with a low serum folate of 2.0 (normal is greater than $2.3 \mathrm{mg} / \mathrm{mL}$ ) had a normal red-blood-cell folate level. The patient with the low red-blood-cell folate of 104 (normal is greater than $140 \mathrm{mg} / \mathrm{mL}$ cells) had a normal serum folate level.

Thus our experience over a $1 \frac{1}{2}$-year period in testing 102 patients suggests that routine serum of red-blood-cell folate as part of a geriatric assessment is of questionable benefit.

Lawrence Z. Feigenbaum, MD Director, San Francisco Institute on Aging, Mount Zion Hospital and Medical Center

DAmON LeE, MD

Fellow in Geriatric Medicine, Mount Zion University of California at San Francisco

\section{REFERENCES}

1. Strachan RW, Henderson JG: Dementia and folate deficiency. Quarterly Journal of Medicine, New Series 36:189-204, 1967

2. Sneath $P$, et al: Folate status in a geriatric population and its relation to dementia. Age and Ageing 2:177, 1973

3. Larson EB, Reifler BV, et al: Diagnostic tests in the evaluation of dementia. Arch Intern Med 146:1917-1922, 1986

4. Freemon F: Evaluation of patients with progressive intellectual deterioration. Arch Neurol 33:658-659, 1976

5. Fox JH, Topel JL, Huckman MS: Dementia in the elderly-A search for treatable illnesses. J Geront 34:557-564, 1975

6. Mulley GP: Differential diagnosis of dementia. Br Med J 292:1416-1418, 1986

7. Delaney P: Dementia: The search for treatable causes South Med J 75:707-709, 1982

\section{Acute Care in Chronic Care Settings}

To the Editor:- The pilot study of Zimmer et $\mathrm{al}^{1}$ confirms what has long appeared self-evident: that substantial savings can be achieved if effective medical and nursing services become available to deal with acute care problems in skilled nursing facilities. Such services require careful patient evaluation, timely visits by attending physicians, intensified nursing care, and ready access to specialized diagnostic and consultative services.

The study also takes note of the fact that hospitalization can be "highly disruptive, physically and mentally, to the patient and may lead to hospital-acquired complications which might not have occurred otherwise." It should be added that, when circumstances allow, better care can of ten be rendered in a skilled nursing facility by personnel who are familiar with each patient's long-term problems, than in an acute hospital setting where a frequently overburdened staff confronts a confused and/or uncooperative patient for the first time. Hospital-acquired complications primarily related to nursing care can be life-threatening, and include malnutrition, infected decubiti, catheter sepsis, and aspiration pneumonia. Many additional problems are generated by cumbersome restrictions imposed by DRGs and utilization review.

In outlining various kinds of parenteral treatment, no mention was made of hypodermoclysis despite an ambiguous reference to "subcutaneous" therapy. Although hypodermoclysis is virtually unknown among a younger generation of physicians and nurses, the procedure offers an exceptionally safe, convenient, and effective means of fluid replacement where adequate oral intake is not feasible and circumstances make the establishment of an IV line difficult or impractical. ${ }^{2}$ Prompt and effective means for rehydrating acutely ill and debilitated patients must always be available.

A final point must be made with respect to physician reimbursement. As presently constituted, the medicare program has a built-in financial incentive favoring hospitalization. Simply put, when a patient is hospitalized the attending physician can be virtually certain that medicare reimbursement will cover the entire length of the patient's stay. Comparable care rendered in a skilled nursing facility would invite either a glut of denied payments or an ongoing battle with the medicare carrier. By showing that fair and equitable reimbursement at the skilled nursing level can produce a reliable system of efficient and cost-effective care, these investigators have performed a distinctive service. It is to be hoped that everyone concerned with the health of our aging population will give their report serious attention. 